\title{
Olaf-prisen 2017 til Kirsti Silvola
}

I ANLEDNING Verdensdagen for selvmordsforebygging ble Olaf-prisen delt ut til spesialrådgiver i RVTS Øst, Kirsti Silvola. Hun fikk prisen for sin pionérinnsats med å bringe Vivat-kurset «Førstehjelp ved selvmordsfare» til Norge, et kurs som over 40000 mennesker nå har tatt på landsbasis. Hun har også bidratt til varige selvmordsforebyggingstiltak giennom å bygge opp den landsdekkende organisasjonen VIVAT Selvmordsforebygging.

Prisutdelingen fant sted på Litteraturhuset i Oslo 4. september, under arrangementet «Selvmordsforebygging: For mye åpenhet?» På programmet stod også foredrag, musikk og samtaler om dilemmaer i mediehverdagen.

\section{Olaf-prisen}

Olaf-prisen (tidligere Olafs Minnepris) er etablert av stiftelsen Olafs Minnefond til forebygging av selvmord blant unge. Prisen tildeles som en anerkjennelse til en person som har bidratt med fremragende vitenskapelig arbeid eller kunnskapsformidling innenfor feltet selvmordsforebygging blant barn og ungdom.

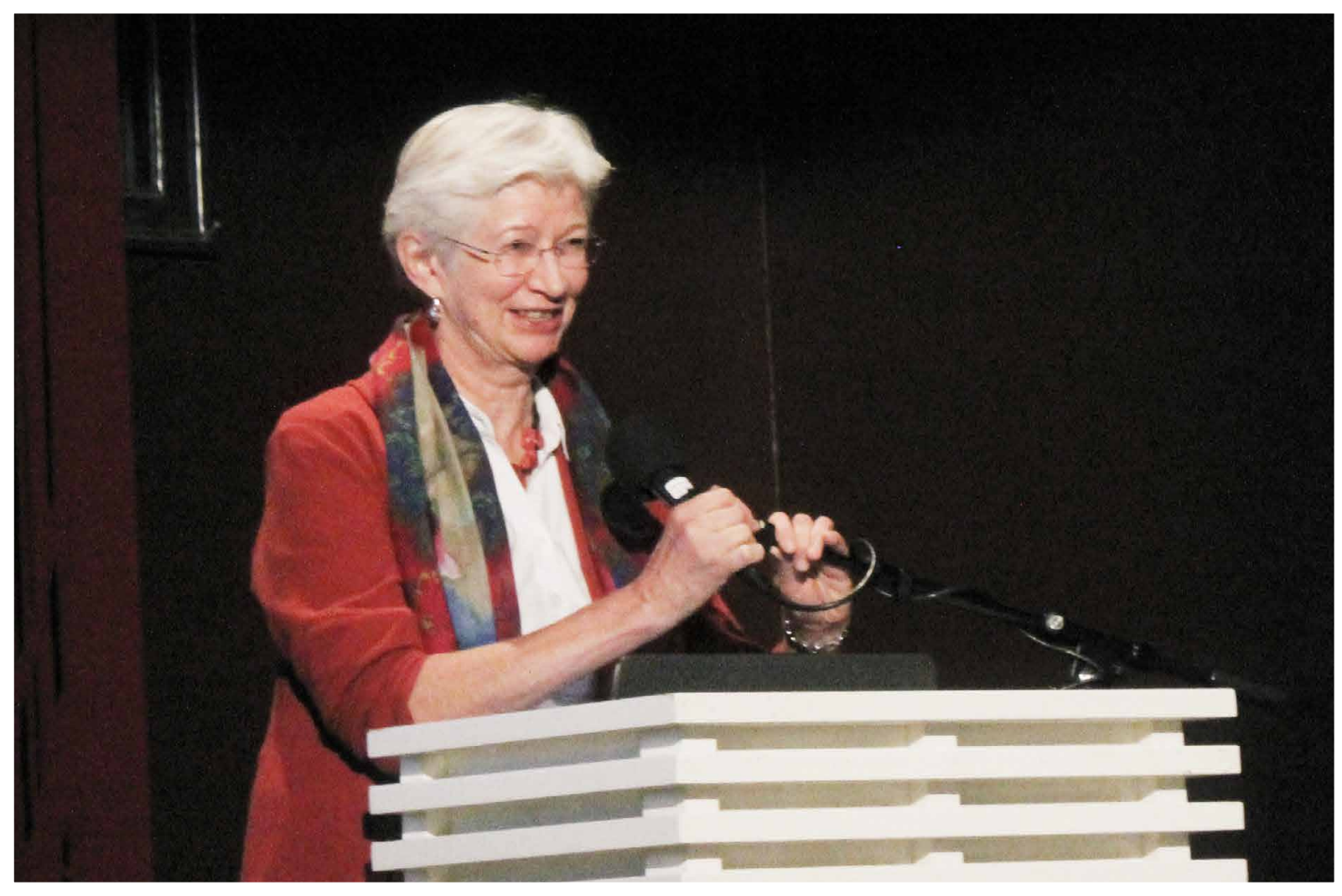

Kirsti Silvola fikk Olaf-prisen 2017 for sitt pionéarbeid med å bringe VIVAT-kurset «Førstehjelp ved selvmordsfare» til Norge, og for å ha bygget opp organisasjonen VIVAT selvmordsforebygging. 